\title{
Towards constraints on fossil fuel emissions from total column carbon dioxide
}

\author{
G. Keppel-Aleks ${ }^{1,2}$, P. O. Wennberg ${ }^{1}$, C. W. O'Dell ${ }^{3}$, and D. Wunch ${ }^{1}$ \\ ${ }^{1}$ California Institute of Technology, Pasadena, CA, USA \\ ${ }^{2}$ University of California, Irvine, CA, USA \\ ${ }^{3}$ Colorado State University, Fort Collins, CO, USA \\ Correspondence to: G. Keppel-Aleks (gka@alum.mit.edu)
}

Received: 1 November 2012 - Published in Atmos. Chem. Phys. Discuss.: 21 November 2012

Revised: 26 February 2013 - Accepted: 22 March 2013 - Published: 26 April 2013

\begin{abstract}
We assess the large-scale, top-down constraints on regional fossil fuel emissions provided by observations of atmospheric total column $\mathrm{CO}_{2}, X_{\mathrm{CO}_{2}}$. Using an atmospheric general circulation model (GCM) with underlying fossil emissions, we determine the influence of regional fossil fuel emissions on global $X_{\mathrm{CO}_{2}}$ fields. We quantify the regional contrasts between source and upwind regions and probe the sensitivity of atmospheric $X_{\mathrm{CO}_{2}}$ to changes in fossil fuel emissions. Regional fossil fuel $X_{\mathrm{CO}_{2}}$ contrasts can exceed 0.7 ppm based on 2007 emission estimates, but have large seasonal variations due to biospheric fluxes. Contamination by clouds reduces the discernible fossil signatures. Nevertheless, our simulations show that atmospheric fossil $X_{\mathrm{CO}_{2}}$ can be tied to its source region and that changes in the regional $X_{\mathrm{CO}_{2}}$ contrasts scale linearly with emissions. We test the GCM results against $X_{\mathrm{CO}_{2}}$ data from the GOSAT satellite. Regional $X_{\mathrm{CO}_{2}}$ contrasts in GOSAT data generally scale with the predictions from the GCM, but the comparison is limited by the moderate precision of and relatively few observations from the satellite. We discuss how this approach may be useful as a policy tool to verify national fossil emissions, as it provides an independent, observational constraint.
\end{abstract}

\section{Introduction}

The atmospheric mixing ratio of $\mathrm{CO}_{2}$ has increased from a preindustrial value of $280 \mathrm{ppm}$ to over $390 \mathrm{ppm}$ in 2011 . This increase is due to anthropogenic activity: in 2008, $8.7 \pm 0.5 \mathrm{PgC}$ were emitted due to fossil fuel combustion, and $1.2 \pm 0.2 \mathrm{PgC}$ were released to the atmosphere from land use change and biomass burning (Le Quéré et al., 2009). Given the risk of global climate change due to increasing atmospheric $\mathrm{CO}_{2}$ (Meehl et al., 2007), the international community has pursued treaties, such as the Kyoto Protocol, to limit the emissions of $\mathrm{CO}_{2}$ to the atmosphere. Currently, the international community relies on self-reporting of greenhouse gas emissions but lacks the ability to verify these reports against independent data (NRC, 2010). A methodology to use observations of atmospheric $\mathrm{CO}_{2}$ to verify national level emissions would therefore be highly desirable to support an international agreement.

Monitoring fossil fuel emissions from atmospheric $\mathrm{CO}_{2}$ observations represents a challenge different from attempts to infer natural carbon fluxes. Knowledge of the distribution and strength of terrestrial and oceanic fluxes of $\mathrm{CO}_{2}$ is determined, at least in part, by assimilating observations of atmospheric $\mathrm{CO}_{2}$ (e.g., Gurney et al., 2002; Peters et al., 2007). In these studies, fossil fuel emissions are assumed to be known at either annual mean or monthly timescales, and only natural fluxes are optimized based on atmospheric observations. Assuming perfect knowledge of fossil emissions alleviates the technical challenge of inferring the net carbon fluxes to the ocean and land (which represent only a small residual of the gross exchange), but introduces bias into the optimized terrestrial and ocean fluxes. For instance, Corbin et al. (2010) show that the surface $\mathrm{CO}_{2}$ mixing ratio can differ by up to $6 \mathrm{ppm}$ in a chemical transport model when fossil fuel emissions are distributed using a coarse grid according to population versus a high-resolution inventory, with implications for inversion results. 
Recently, progress has been made in bottom-up monitoring for fossil fuel $\mathrm{CO}_{2}$ emission attribution from point sources such as power plants (e.g., Bovensmann et al., 2010 and Velazco et al., 2011) and from urban areas (e.g., Turnbull et al., 2011 and Newman et al., 2012). Results from Los Angeles suggest that fossil fuel enhancements over a megacity are large enough (around $3 \mathrm{ppm}$ ) to be observed in the total column (the vertically integrated mass of $\mathrm{CO}_{2}$ in the atmosphere above a given location) via satellite observations (Wunch et al., 2009; Newman et al., 2012; Kort et al., 2012). Total column $\mathrm{CO}_{2}$ (denoted $X_{\mathrm{CO}_{2}}$ ) is currently measured by satellites such as SCIAMACHY (e.g., Buchwitz et al., 2005 and Schneising et al., 2011) and GOSAT (Yokota et al., 2004), and will be measured by the upcoming OCO-2 satellite. Analysis of SCIAMACHY data has shown that regional $\mathrm{XCO}_{2}$ enhancements over industrial regions are detectible from space and are of order $\sim 1.5 \mathrm{ppm}$ over the Rhine-Main region of Germany (Schneising et al., 2008). Ground-based measurements of $X_{\mathrm{CO}_{2}}$ are obtained by spectrometers in the Total Carbon Column Observing Network (TCCON) (Wunch et al., 2011). Observations over megacities, urban areas, and large power plants are likely to show large enhancements in $\mathrm{CO}_{2}$ and provide improved processlevel constraints on emissions from various sources and sectors (Duren and Miller, 2012). However, they do not completely bridge the gap between bottom-up inventories and the top-down observational constraints on the spatial scale necessary for complete verification of national level emissions. In this paper, we therefore attempt to explore the signature of fossil fuel emissions on regional scales.

We use a general circulation model (GCM) with imposed surface fluxes to explore the sensitivity of $X_{\mathrm{CO}_{2}}$ to fossil emissions in a framework in which we can easily adjust fluxes or modulate assumptions about vertical mixing rates. Our goal is to investigate the potential for using total column $\mathrm{CO}_{2}$ observations from satellites to verify trends in fossil fuel emissions rather than to account for the absolute magnitude of emissions. We illustrate a data-driven approach in which aggregated $X_{\mathrm{CO}_{2}}$ fields are differenced over emission and upwind regions to determine fossil fuel $\mathrm{CO}_{2}$ emissions. The value of this approach lies in its simplicity. Because fossil emissions are spatially concentrated, the atmosphere retains a fossil signature that can be used to constrain fluxes from observations. Regional differencing of fossil fuel $\mathrm{CO}_{2}$ may be complementary to observations of more localized fossil fuel $\mathrm{CO}_{2}$ sources. Detecting large-scale, zonally asymmetric patterns in $X_{\mathrm{CO}_{2}}$ could also be beneficial for determining compliance in areas where treaty commitments take account of reduced deforestation or improved soil management. Schneising et al. (2011) made use of the zonal asymmetry in SCIAMACHY $\mathrm{XCO}_{2}$ to estimate the relative contributions of North America and Eurasia to boreal $\mathrm{CO}_{2}$ uptake.

In this paper, we present results from simulated and observed $X_{\mathrm{CO}_{2}}$ fields. In Sect. 2, we describe the model used to simulate $X_{\mathrm{CO}_{2}}$ fields from surface flux estimates. In Sect. 3 ,

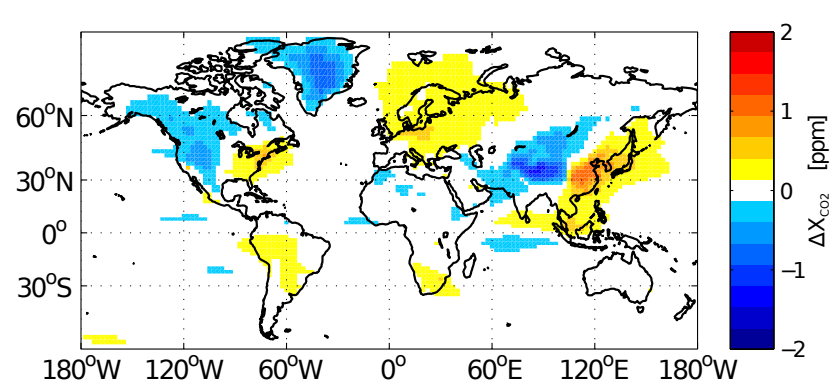

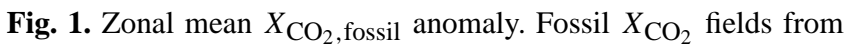
the AM2 GCM are averaged for one year and detrended by the zonal mean to more clearly show the influence of source regions on global $X_{\mathrm{CO}_{2}}$.

we describe the ACOS-GOSAT (Atmospheric $\mathrm{CO}_{2}$ Observations from Space-Greenhouse Gases Observing Satellite) $X_{\mathrm{CO}_{2}}$. In Sect. 4, we discuss the simulated regional contrasts from fossil fuel emissions and the potential complications that may hinder observation of contrasts from space. We also present results using ACOS-GOSAT data in Sect. 4. Finally, Sect. 5 contains discussion relating to a strategy for observing fossil $X_{\mathrm{CO}_{2}}$ from space.

\section{Model}

We simulate $X_{\mathrm{CO}_{2}}$ fields with an atmospheric general circulation model (GCM), using carbon fluxes as boundary conditions. We use the AM2 GCM developed at the NOAA Geophysical Fluid Dynamics Laboratory (Anderson et al., 2004), run at $2^{\circ}$ latitude $\times 2.5^{\circ}$ longitude resolution with 25 vertical levels. We separately track atmospheric $X_{\mathrm{CO}_{2} \text {, fossil }}, X_{\mathrm{CO}_{2} \text {, bio }}$,

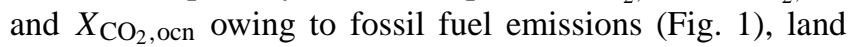
biosphere exchange, and oceanic exchange, respectively, in AM2.

Fossil emissions are based on monthly mean emissions for the year 2007 (Andres et al., 2011), when net global emissions were $8.1 \mathrm{Pg} \mathrm{C} \mathrm{yr}^{-1}$. Since then, Chinese emissions have increased by at least $25 \%$, but the growth in emissions from other developed nations slowed from 2008-2009 during the global recession (Boden et al., 2012; Friedlingstein, 2010). The fossil emissions are determined from a proportionalproxy method, in which self-reported fuel consumption data are compiled for countries, where available, on monthly timescales. Countries that lack data at monthly resolution are paired with a proxy country based on similarities in climate and economics, and self-reported annual emissions are distributed at monthly time steps based on patterns in the proxy country (Gregg and Andres, 2008). The geographic distribution of fluxes is determined from energy and electricity consumption, where available; otherwise emissions are gridded based on population (Marland and Rotty, 1984).

In addition to fossil fluxes, we include biospheric and oceanic fluxes in AM2. Biosphere-atmosphere exchange in 
Table 1. Source regions for fossil fuel $\mathrm{CO}_{2}$. The integrated emissions for 2007 are from Andres et al. (2011) and are used for AM2 simulations.

\begin{tabular}{lllc}
\hline $\begin{array}{l}\text { Emission } \\
\text { Region }\end{array}$ & Latitude & Longitude & $\begin{array}{c}2007 \text { emissions } \\
{\left[\mathrm{Pg} \mathrm{C} \mathrm{yr}^{-1}\right]}\end{array}$ \\
\hline Europe & $32-65^{\circ} \mathrm{N}$ & $20^{\circ} \mathrm{W}-28^{\circ} \mathrm{E}$ & 1.2 \\
India & $7-33^{\circ} \mathrm{N}$ & $68-88^{\circ} \mathrm{E}$ & 0.4 \\
China & $20-48^{\circ} \mathrm{N}$ & $100-135^{\circ} \mathrm{E}$ & 2.1 \\
W. N. Am & $30-55^{\circ} \mathrm{N}$ & $110-125^{\circ} \mathrm{W}$ & 0.3 \\
E. N. Am & $25-55^{\circ} \mathrm{N}$ & $60-110^{\circ} \mathrm{W}$ & 1.4 \\
Australia & $20-45^{\circ} \mathrm{S}$ & $110-155^{\circ} \mathrm{E}$ & 0.1 \\
\hline
\end{tabular}

the AM2 simulations is based on monthly CASA fluxes (Randerson et al., 1997). The monthly exchange is derived from a climatological mean and is approximately zero at each grid box across the annual cycle. The monthly exchange is distributed across each month at three-hourly time steps based on the year 2000 meteorology (Olsen and Randerson, 2004). We have increased CASA net ecosystem exchange by $40 \%$ integrated across the boreal region from $40^{\circ}$ to $70^{\circ}$ because TCCON data and CarbonTracker reanalysis fluxes suggest that CASA underestimates summer drawdown (Keppel-Aleks et al., 2012). Ocean surface fluxes are prescribed as monthly-mean fluxes derived from surface ocean $p \mathrm{CO}_{2}$ data (Takahashi et al., 2002). These ocean fluxes represent an annual and global mean sink of atmospheric $\mathrm{CO}_{2}$ of $1.4 \mathrm{Pg} \mathrm{C} \mathrm{yr}^{-1}$.

We investigate the influence of six source regions on

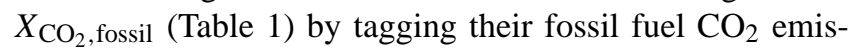
sions in $\mathrm{AM} 2$. We quantify the resulting difference in $X_{\mathrm{CO}_{2} \text {, fossil }}$ and $X_{\mathrm{CO}_{2} \text {, bio over aggregated regions, as regional }}$ differences in $X_{\mathrm{CO}_{2} \text {,ocn }}$ are quite small. For each study region, we calculate the $X_{\mathrm{CO}_{2}}$ contrast as the difference between a region that is directly affected by emissions and an "upwind" region.

Rather than use geographically defined regions to average the data, we define the north-south boundaries based on potential temperature, $\theta$. In simulations with zonally uniform surface fluxes, $X_{\mathrm{CO}_{2}}$ is tightly correlated with potential temperature, $\theta$ (Keppel-Aleks et al. (2011), their Fig. 12). Therefore, in absence of zonal asymmetry in fluxes, isentropic regions would yield contrasts of zero, while flux asymmetries introduced by fossil and biospheric fluxes would yield observable regional contrasts. In AM2 simulations, the seasonal cycle in the biospheric contrast between source and upwind regions is reduced by up to $1 \mathrm{ppm}$ when using averaging regions defined by potential temperature rather than fixed geographic coordinates, while the magnitude of the simulated fossil contrast is not affected. To implement dynamically defined regions, we fix the coordinates at the northeast and southeast edge of the emission region and calculate the monthly mean $\theta$ at $700 \mathrm{hPa}$ at these coordinates (Fig. 2). The potential temperature contours that intersect these ver-
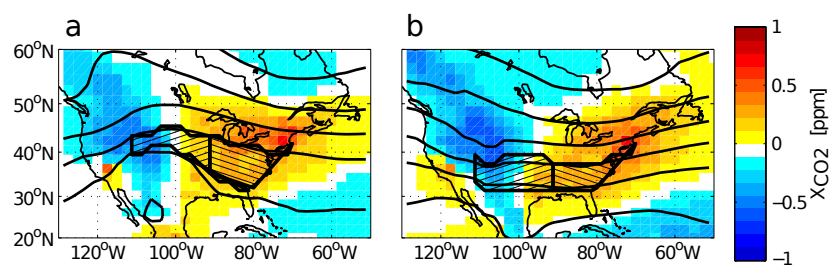

Fig. 2. (a) May and (b) November dynamically adaptive regions over eastern North America. The eastern and western edges of the emission and upwind regions are determined based on contrasts in simulated $X_{\mathrm{CO}_{2}}$, while the north and south boundaries follow isentropes.

tices then define the northern and southern boundaries of the emission and upwind regions. The east-west boundaries are informed by the zonal anomaly in $X_{\mathrm{CO}_{2} \text {,fossil in AM2 }}$ and are fixed on an annual basis. Although the geographic boundaries of the regions change each month, this approach provides a semi-Lagrangian averaging framework. For India, where wind direction reverses seasonally with the monsoon and where temperature gradients are small, we cannot use $\theta$ to define a dynamical region and instead use geographically fixed coordinates.

\section{Data}

We analyze ACOS-GOSAT $X_{\mathrm{CO}_{2}}$ data retrieved from spectra obtained between April 2009 and March 2011. GOSAT is a carbon-observing satellite developed jointly by the Japanese Ministry of the Environment, the National Institute for Environmental Studies, and the Japan Aerospace Exploration Agency. GOSAT samples the same location every three days and has a nadir footprint of $10.5 \mathrm{~km}$ diameter $\left(86.6 \mathrm{~km}^{2}\right.$ area). Details about the retrieval method are provided by O'Dell et al. (2012). We primarily present results using ACOS-GOSAT v 2.9 retrievals, although we have also analyzed preliminary ACOS-GOSAT $\vee 2.10$ retrievals to test the sensitivity of our results to the retrieval. Because only data obtained over the land have been validated to date, we test our predictions regarding regional contrasts over China and the eastern United States, where the corresponding upwind regions are over land. We also analyze contrasts for regions where we expect minimal contribution from fossil emissions, including Australia and the upwind-of-China region, for which we average ACOS-GOSAT $X_{\mathrm{CO}_{2}}$ from a region further upwind to calculate a regional ACOS-GOSAT $X_{\mathrm{CO}_{2}}$ contrast. We filter the data and apply appropriate bias corrections as detailed in Wunch et al. (2011b). We also average ACOS-GOSAT data obtained in target mode to determine "unique" data points and not over-weight observations over targeted regions.

We define dynamically adaptive regions for averaging the ACOS-GOSAT data using the same method as for AM2. The 


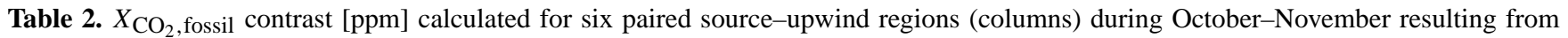
emissions from tagged source regions (rows) and from global emissions. We use dynamically adaptive emission and upwind regions to calculate the contrasts, except for India where we defined stationary averaging boxes. Each source-upwind regional contrast is dominated by its own emissions.

\begin{tabular}{l|rrrrrr}
\hline \multirow{2}{*}{ Fossil Source } & \multicolumn{5}{c}{ Contrast between emission and upwind region [ppm] } \\
\cline { 2 - 7 } & Europe & India & China & W. N. Am. & E. N. Am. & Australia \\
\hline Europe & 0.30 & -0.01 & -0.03 & -0.01 & -0.03 & -0.03 \\
India & 0.00 & 0.14 & 0.00 & 0.01 & -0.01 & -0.01 \\
China & 0.08 & 0.00 & 0.58 & 0.01 & 0.07 & 0.01 \\
W. N. Am & -0.02 & 0.01 & -0.04 & -0.07 & -0.01 & -0.00 \\
E. N. Am & 0.01 & -0.00 & 0.01 & -0.02 & 0.24 & -0.00 \\
Australia & 0.00 & 0.00 & -0.02 & 0.01 & -0.00 & 0.01 \\
\hline Global & 0.26 & 0.08 & 0.76 & -0.04 & 0.25 & -0.35 \\
\hline
\end{tabular}

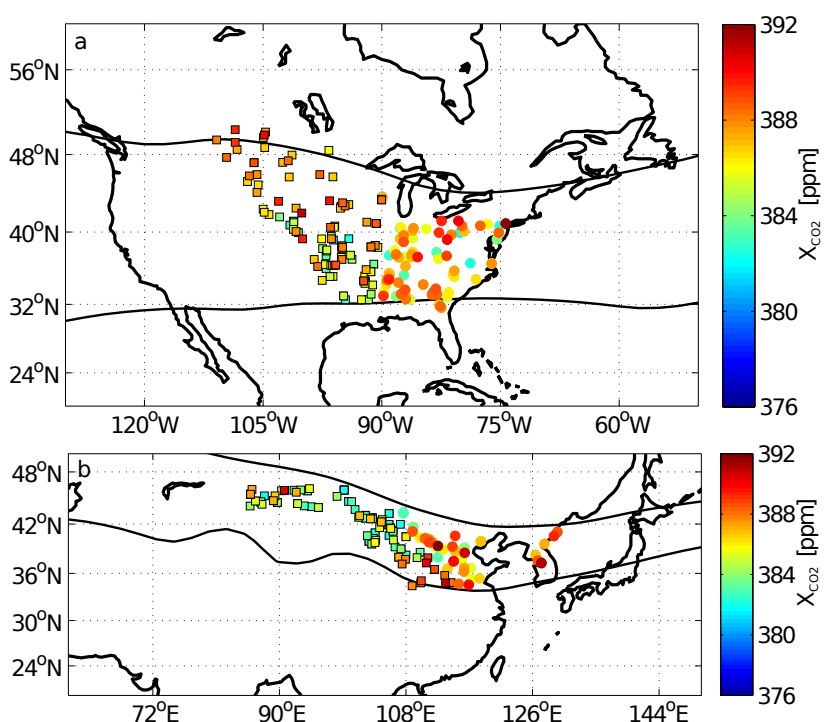

Fig. 3. October 2009-2010 GOSAT $X_{\mathrm{CO}_{2}}$ data for two major source regions: (a) eastern North America and (b) China. Circles represent data in the emission region, and squares represent data in the upwind region. The monthly mean potential temperature contours that define the northern and southern boundaries are also plotted, but individual data can lie outside these contours due to synoptic variability. Although individual retrievals are quite variable, there is a $0.6 \pm 0.2 \mathrm{ppm}$ contrast between the source and upwind region over eastern North America and a $1.9 \pm 0.4$ ppm contrast over China during Northern Hemisphere autumn (Table 3).

eastern and western boundaries for the emission and upwind regions are the same as for AM2, and we use NCEP reanalysis potential temperature (Kalnay et al., 1996) to determine the north and south boundaries (Fig. 3). To estimate the potential sampling bias in the ACOS-GOSAT contrasts, we compare the observations against AM2 sampled using two different approaches: at all grid boxes within the dynamically defined emission and upwind regions, and only at grid boxes containing ACOS-GOSAT retrievals. We average data from
2009-2011 to improve the statistics, assuming no interannual variability, a reasonable assumption for fossil fuel emissions between 2009 and 2011 (Boden et al., 2012). Although ground-based observations of $X_{\mathrm{CO}_{2}}$ show substantial interannual variability due to biospheric fluxes, we do not attempt to account for the variability in $X_{\mathrm{CO}_{2}}$, bio in the present study. To compare with AM2, we have increased the simulated Chinese $X_{\mathrm{CO}_{2}}$ contrast by $25 \%$ of the tagged Chinese $X_{\mathrm{CO}_{2} \text {, fossil }}$ contrast to account for the increased emissions compared to 2007 (Boden et al., 2012).

\section{Results}

\subsection{Simulations}

The signal in $X_{\mathrm{CO}_{2}}$ from fossil fuel emissions is small. The

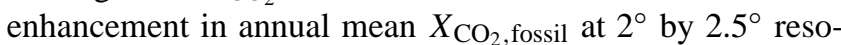
lution is at most $1.5 \mathrm{ppm}$ above the zonal mean for any grid cell (Fig. 1). As expected, the largest anomalies are over regions with large fossil fuel emissions (e.g., the eastern United States, Europe, and China).

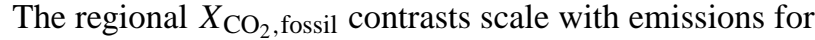
the six source regions (Table 2). For regions with the largest emissions (eastern US, Europe, and China), fossil fuel emissions impart a potentially detectable regional contrast of 0.2 $0.8 \mathrm{ppm}$, while regions with smaller total emissions have

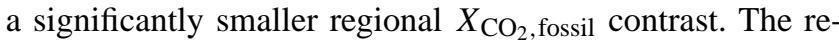
gional contrasts are smaller than those expected over locations with concentrated emissions, such as megacities, which show enhancements of $\sim 3$ ppm (Kort et al., 2012). Local fossil emissions account for a large fraction of the $X_{\mathrm{CO}_{2} \text {, fossil }}$ contrast in the simulations (Table 2). The contributions to the

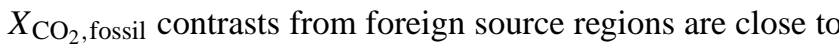
zero, meaning that the contrasts primarily reflect local emis-

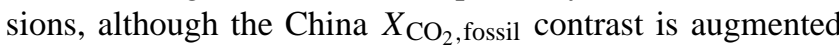
by emissions from elsewhere in Asia.

On a seasonal basis, the regional contrasts in $X_{\mathrm{CO}_{2}}$ owing to fossil fuel emissions are partially obscured even in 


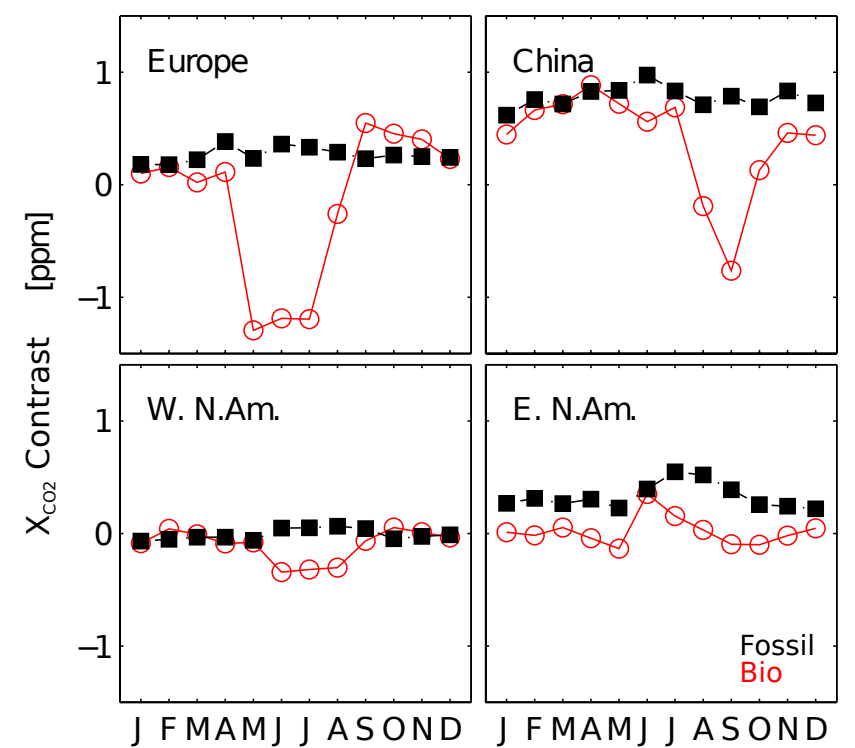

Fig. 4. Simulated regional contrast in $X_{\mathrm{CO}_{2} \text {, bio }}$ (red) and

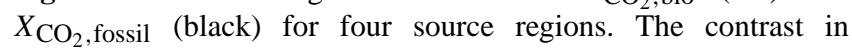
$X_{\mathrm{CO}_{2} \text {, fossil between emission and upwind regions generally scales }}$ with emissions (Table 1) and is less seasonal than the biospheric contrast.

the largest source regions by seasonally varying biospheric fluxes (Fig. 4). We do not show the contribution from ocean fluxes in AM2 since they cause only small (well under $0.1 \mathrm{ppm}$ ) spatial variations in the column. Although the regional biospheric contrast is minimized by the use of the semi-Lagrangian averaging regions, growing season contrasts are of the order of $1 \mathrm{ppm}$ for Europe and China, suggesting that the fossil fuel signal may be more clear in satellite data acquired outside the growing season.

Seasonal patterns in $X_{\mathrm{CO}_{2}}$ variability on synoptic scales also impact the detectability of contrasts in the fossil component of $X_{\mathrm{CO}_{2}}$. Biospheric fluxes primarily determine the large-scale gradient in $X_{\mathrm{CO}_{2}}$, and advection of those gradients is the dominant source of temporal variations in $X_{\mathrm{CO}_{2}}$ (Keppel-Aleks et al., 2011). While these variations provide a useful tool to infer the large-scale gradient in $X_{\mathrm{CO}_{2}}$ when measured at a single site on a continuous basis (such as from ground-based TCCON observatories), they complicate the interpretation of most satellite data, where observations are made at low temporal resolution. Synoptic variability in $\mathrm{CO}_{2}$ is relatively small when large-scale gradients are small, but during the Northern Hemisphere growing season, synoptic activity induces RMS variability of the order of $3 \mathrm{ppm}$ in the Northern Hemisphere midlatitudes focused along the storm tracks, coincident with the regions in which substantial fossil fluxes occur (Fig. 5a and b). That the variations are smaller outside the growing season again suggests that the signal from fossil fluxes should be easier to diagnose in winter and autumn.

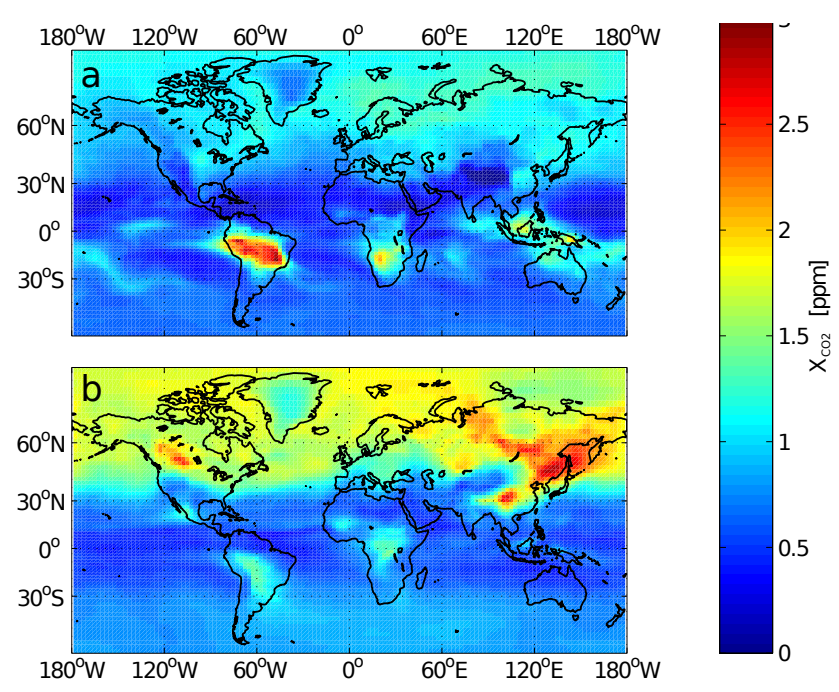

Fig. 5. Simulated seasonal variability in $X_{\mathrm{CO}_{2}}$. (a) RMS variability for January-February and (b) July-August. Synoptic scale RMS variability is maximized in the Northern Hemisphere during the growing season, when large-scale gradients are maximal.

As expected for a passive tracer like $\mathrm{CO}_{2}$, the constructed contrasts scale linearly with emissions. The $X_{\mathrm{CO}_{2}}$,fossil contrasts for the six study regions increase by a factor of

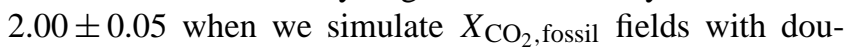
bled global emissions. To further verify linearity, we sim-

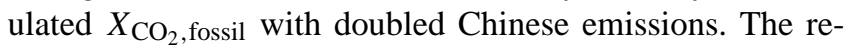
sulting contrasts were equal to the sum of the contrasts from base global emissions plus the contrasts from tagged Chinese emissions.

The residence time of fossil $\mathrm{CO}_{2}$ within the defined emission region affects the expected contrast. To test the sensitivity of the contrast to the residence time, we run the AM2 with fossil fluxes emitted in the free troposphere $(650 \pm 50 \mathrm{hPa})$ rather than at the surface, which is likely an overestimate of the potential error in the simulated regional signal if vertical mixing rates are underestimated. The mean contrasts decrease by $30 \pm 10 \%$ due to faster transport times of $\mathrm{CO}_{2}$ away from the emission region. The residence time for fossil emissions varies from region to region, so we do not seek to relate the observed contrasts directly to emissions, but rather to the change in emissions over time, assuming that mean transport times remain stable on decadal timescales.

The regional contrasts described above are computed from all grid boxes in the dynamically defined regions regardless of cloud cover; in reality, remote sensing observations of $X_{\mathrm{CO}_{2} \text {, fossil }}$ are obtained only under clear-sky conditions, which may induce a bias in the regional contrasts. In AM2, the calculated regional fossil contrasts generally decrease relative to the all-sky value when grid boxes with fractional cloud cover above a threshold value are excluded from the regional averages (Fig. 6). The sensitivity varies substantially by region: for instance, the regional contrast over 
Table 3. $X_{\mathrm{CO}_{2}}$ contrast [ppm] for ACOS GOSAT data and AM2 simulations. The AM2 partial contrast is sampled coincidently with GOSAT data. AM2 full contrasts average all model grid boxes within the dynamically defined regions for all days within the season. The number in parentheses indicates the regional contrast owing only to fossil fuel emissions. Error estimates represent the standard error of the mean. GOSAT data are averaged for two years across four seasons: winter (January-February), spring (April-May), summer (July-August), and fall (October-November), with the number of points in the ACOS emission and upwind region listed seasonally.

\begin{tabular}{llrrrr}
\hline Season & & China & China upwind & E. N. Am. & Australia \\
\hline \multirow{6}{*}{ Winter } & GOSAT contrast & $1.7 \pm 0.4$ & $0.1 \pm 0.6$ & $0.0 \pm 0.4$ & $0.4 \pm 0.3$ \\
& AM2 partial & $0.9(0.4) \pm 0.1$ & $-0.5(-0.5) \pm 0.1$ & $0.2(0.3) \pm 0.1$ & $0.4(0.0) \pm 0.2$ \\
& AM2 full & $1.4(1.1) \pm 0.2$ & $-0.7(-0.4) \pm 0.3$ & $0.4(0.4) \pm 0.2$ & $0.0(-0.1) \pm 0.1$ \\
& $N$ & 120 & 107 & 135 & 62 \\
& $N_{\text {upwind }}$ & 107 & 31 & 153 & 10 \\
\hline \multirow{5}{*}{ Spring } & GOSAT contrast & $1.0 \pm 0.4$ & $-1.2 \pm 0.4$ & $0.4 \pm 0.2$ & $-0.6 \pm 0.3$ \\
& AM2 partial & $1.7(0.6) \pm 0.1$ & $-1.0(-0.3) \pm 0.1$ & $0.3(0.2) \pm 0.1$ & $-0.1(0.0) \pm 0.1$ \\
& AM2 full & $0.7(0.4) \pm 0.3$ & $-0.2(-0.1) \pm 0.2$ & $0.3(0.3) \pm 0.2$ & $0.2(0.0) \pm 0.1$ \\
& $N$ & 53 & 82 & 125 & 70 \\
& $N_{\text {upwind }}$ & 82 & 71 & 105 & 33 \\
\hline \multirow{5}{*}{ Summer } & GOSAT contrast & $-0.6 \pm 0.4$ & $-1.3 \pm 0.5$ & $0.5 \pm 0.5$ & $-0.5 \pm 0$. \\
& AM2 partial & $-0.3(0.3) \pm 0.2$ & $-1.3(-0.1) \pm 0.2$ & $0.5(0.5) \pm 0.2$ & $-0.5(-0.3) \pm 0.1$ \\
& AM2 full & $1.2(0.9) \pm 0.4$ & $-0.5(-0.1) \pm 0.2$ & $1.1(0.8) \pm 0.5$ & $0.0(0.0) \pm 0.1$ \\
& $N$ & 64 & 71 & 65 & 107 \\
& $N_{\text {upwind }}$ & 71 & 41 & 104 & 110 \\
\hline \multirow{6}{*}{ Fall } & GOSAT contrast & $1.9 \pm 0.4$ & $0.2 \pm 0.3$ & $0.6 \pm 0.2$ & $0.0 \pm 0$. \\
& AM2 partial & $1.1(0.9) \pm 0.1$ & $-0.2(-0.3) \pm 0.1$ & $0.6(0.3) \pm 0.1$ & $0.0(-0.3) \pm 0.1$ \\
& AM2 full & $1.5(1.0) \pm 0.3$ & $0.1(0.0) \pm 0.1$ & $0.3(0.4) \pm 0.1$ & $-0.1(-0.1) \pm 0.1$ \\
& $N$ & 98 & 203 & 178 & 65 \\
& $N_{\text {upwind }}$ & 203 & 172 & 198 & 35 \\
\hline
\end{tabular}

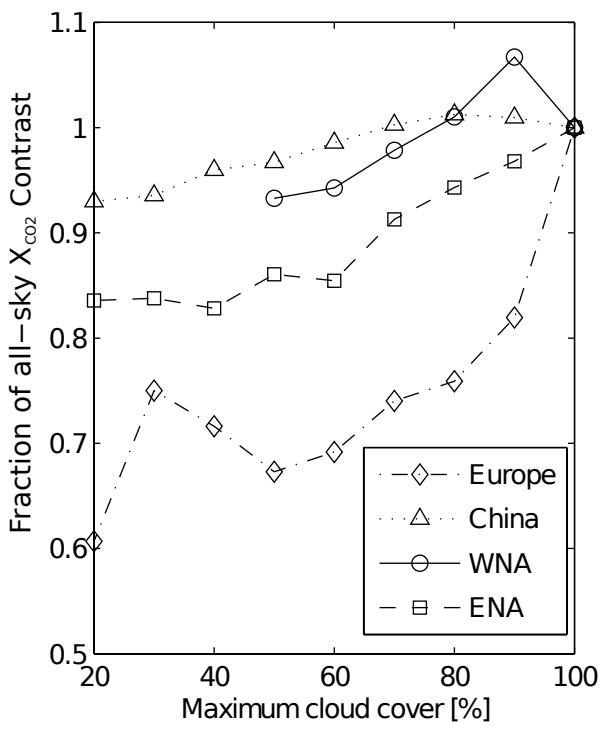

Fig. 6. Relative change in the simulated $X_{\mathrm{CO}_{2}}$ contrast for four source regions when data are excluded due to cloud cover in the model grid cell exceeding a threshold value.
China and western North America decreases by less than $10 \%$ when the cloud threshold is $50 \%$. In contrast, eastern North America and European regional fossil contrasts decrease by $20 \%$ and $30 \%$ with a $50 \%$ cloud threshold. The cloud bias in AM2 simulations results from clouds preferentially obscuring AM2 grid boxes whose $X_{\mathrm{CO}_{2} \text {, fossil con- }}$ centrations are higher than the regional average. AM2 does not include aerosols, which, at high optical depth, would limit satellite retrievals similarly to clouds. Since $\mathrm{CO}_{2}$,fossil and aerosol share anthropogenic sources, high $X_{\mathrm{CO}_{2} \text {, fossil and }}$ high aerosol optical depth may be spatially correlated, which could lead to further bias in the regional contrasts. We recommend that the bias from cloud cover be investigated in a transport model that includes both anthropogenic aerosols and interactions between meteorology and biospheric fluxes.

\subsection{Comparison with ACOS-GOSAT data}

The regional contrasts in ACOS-GOSAT data are of the magnitude we expect based on the AM2 simulations and generally scale with fossil fuel emissions for the major emission regions (China and the eastern United States, Table 3). The comparison reveals two initial complications. First, the sampling bias for AM2 is large (up to $1 \mathrm{ppm}$ ) between a GOSAT-like sampling and a spatially and temporally complete sampling (e.g., the spring contrast over China). Second, 
the upwind-of-China and Australia regions, which were chosen to test the agreement between AM2 and observations where fossil emissions are small, show significant regional contrasts likely owing to biospheric patterns. As expected based on the simulations, these biases are minimized during Northern Hemisphere winter (January-February) and autumn (October-November) when biospheric fluxes are more quiescent and zonal flux anomalies are dominated by the fossil fuel component.

In winter and autumn, the comparison between ACOSGOSAT observations and AM2 agrees well for the eastern United States when we sample AM2 only where we have ACOS-GOSAT observations. For China, the comparison between observations and simulations is more favorable when AM2 is sampled everywhere within the emission and upwind regions. Still, the observed ACOS-GOSAT enhancement over the Chinese emission region is larger than that predicted by AM2, even with a $25 \%$ increase added to the simu-

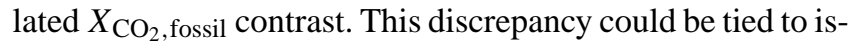
sues with either the ACOS-GOSAT observations or the simulations. An aerosol-induced $X_{\mathrm{CO}_{2}}$ bias may have inflated the observed contrast, or an underestimate in CDIAC Chinese fossil fuel emissions (e.g., Zhao et al., 2012 and Guan et al., 2012) or CASA NEE may have resulted in a biased simulated contrast. The regional contrast observed over the source and upwind regions of China is similar for all three seasons outside the Northern Hemisphere growing season. It is worth noting that only a small dataset that passed all the appropriate quality flags was used to calculate the regional contrasts and their standard errors (Table 3 ).

We tested the effect of the retrieval by computing the seasonal contrasts using non-bias-corrected ACOS-GOSAT v 2.9 retrievals and found that the observed contrasts changed by $\pm 0.2-0.5 \mathrm{ppm}$, with no consistent sign difference. We also calculated regional contrasts using preliminary ACOSGOSAT v 2.10 retrievals with more restrictive quality flags compared to $\mathrm{v} 2.9$, reducing the number of retrievals used to compute the regional averages. The calculated contrasts agreed with those presented in Table 3 to within the standard errors; however the error bars were much larger due to the reduced number of data.

\section{Conclusions}

Our analysis with simulated $X_{\mathrm{CO}_{2}}$ fields suggests that fossil $\mathrm{CO}_{2}$ emissions leave discernible signatures on global $X_{\mathrm{CO}_{2}}$ fields, although these signatures are small and their detection is complicated by variation in natural atmospheric $\mathrm{CO}_{2}$. The simulations show that the fossil signatures respond linearly to changes in fossil emissions. Therefore, changes in observed $X_{\mathrm{CO}_{2}}$ contrasts could be used to monitor changes in fossil emissions.

Two year seasonal averages of regional contrasts in the ACOS-GOSAT data scale with our expectations based on
AM2 simulations, even though the contrasts did not quantitatively agree with the simulations year-round. At least some of the difference comes from sampling bias: regional contrasts are different in the model when we sample only at locations with ACOS-GOSAT retrievals versus when we sample everywhere within the dynamical boundaries. The remaining disagreement could be due to differences in the fossil fluxes underlying the model and actual emissions, due to differences in biospheric fluxes, or due to bias in the observations due to cloud or aerosol contamination. The emissions underlying AM2 in our experiments are based on CDIAC flux estimates, which Guan et al. (2012) estimate are $10 \%$ below Chinese emissions estimated from province-level statistics and that Zhao et al. (2012) estimate are $10 \%$ below emissions determined from a bottom-up Monte Carlo model. The simulations also show that regional biospheric enhancements will potentially obscure fossil fuel signatures, consistent with observations of $\mathrm{CO}_{2}$ made in China and Korea that show up to $50 \%$ of the boundary layer enhancement in polluted regions is owed to biospheric emissions (Turnbull et al., 2011b).

Although the initial comparison presented here between simulations and observations demonstrates that estimating fossil fuel emissions from space will be difficult, our results provide direction for making $X_{\mathrm{CO}_{2}}$ a more useful observation for validating fossil fuel emissions. Both the sampling bias in AM2 (Table 3) and the cloud bias (Fig. 6) point toward footprint size as a key design factor in the utility of satellite observations for fossil fuel emissions monitoring at policy-relevant accuracy. OCO-2 or CarbonSat, whose footprints are 40 and 20 times smaller than that of GOSAT, may be an easier dataset from which to diagnose fossil emission trends as the likelihood of cloud-free scenes will be greater and the spatial coverage will therefore be more complete. Geostationary observations may also reduce the cloud bias by providing multiple retrievals of a given scene each day (Duren and Miller, 2012).

Our results show that the regional contrasts estimated from bias-corrected ACOS-GOSAT data agree better with predictions from AM2, which underscore the importance of careful characterization of satellite retrievals and of an accurate bias correction. We note optimistically that retrievals from GOSAT will likely improve as the retrieval algorithm is further developed and potential sources of bias are better characterized. The launch of OCO-2 and other satellites will provide more, and potentially better, datasets with which to work. For example, OCO-2 requires single-sounding precision of $1 \mathrm{ppm}$ (Miller et al., 2007; Wunch et al., 2011b), slightly better than the single-sounding precision of 1.0 $1.5 \mathrm{ppm}$ for ACOS-GOSAT data (O'Dell et al., 2012). Additionally, the upcoming CarbonSat will provide coincident methane retrievals that may elucidate the processes contributing to regional variations in $\mathrm{X}_{\mathrm{CO}_{2}}$ (Bovensmann et al., 2010).

The method described here is certainly not the most precise method to infer emissions rates from $X_{\mathrm{CO}_{2}}$ observations. 
Techniques such as data assimilation or flux inversions should provide more precise flux estimates and will be necessary to account for interannual variability in natural $\mathrm{CO}_{2}$ fluxes, which we have ignored in this analysis. Moreover, analysis of how concomitant changes in land fluxes and ocean fluxes will accompany decadal-scale increases in fossil fuel emissions is necessary as coherent regional changes may obscure detection of fossil signatures. The methodology presented in this paper represents one tool that can be used in conjunction with other observations at other spatial scales to move toward national-level emissions verification.

Acknowledgements. The satellite data were produced by the ACOS/OCO-2 project at the Jet Propulsion Laboratory, California Institute of Technology. The spectra were acquired by the GOSAT project. Support for this work from NASA grants NNX11AG016, NNX08AI86G, and NNX10AT83G is gratefully acknowledged. We acknowledge the Keck Institute for Space Studies for inspiring this study. GKA acknowledges support from a NOAA Climate and Global Change postdoctoral fellowship.

Edited by: I. Aben

\section{References}

Anderson, J. L., Balaji, V., Broccoli, A. J., Cooke, W. F., Delworth, T. L., Dixon, K. W., Donner, L. J., Dunne, K. A., Freidenreich, S. M., Garner, S. T., Gudgel, R. G., Gordon, C. T., Held, I. M., Hemler, R. S., Horowitz, L. W., Klein, S. A., Knutson, T. R., Kushner, P. J., Langenhost, A. R., Lau, N. C., Liang, Z., Malyshev, S. L., Milly, P. C. D., Nath, M. J., Ploshay, J. J., Ramaswamy, V., Schwarzkopf, M. D., Shevliakova, E., Sirutis, J. J., Soden, B. J., Stern, W. F., Thompson, L. A., Wilson, R. J., Wittenberg, A. T., and Wyman, B. L.: The new GFDL global atmosphere and land model AM2-LM2: Evaluation with prescribed SST simulations, J. Climate, 17, 4641-4673, 2004.

Andres, R. J., Marland, G., Fung, I., and Matthews, E.: A Distribution of Carbon Dioxide Emissions From Fossil Fuel Consumption and Cement Manufacture, Global Biogeochem. Cy., 10, 419-429, doi:10.1029/96GB01523, 1996.

Andres, R. J., Gregg, J. S., Losey, L., Marland, G., and Boden, T. A.: Monthly, global emissions of carbon dioxide from fossil fuel consumption, Tellus B, 63, 309-327, doi:10.1111/j.16000889.2011.00530.x, 2011.

Boden, T., Marland, G., and Andres, R.: Global, regional, and national fossil-fuel $\mathrm{CO}_{2}$ emissions, Carbon Dioxide Information Analysis Center, Oak Ridge National Laboratory, US Department of Energy, Oak Ridge, Tenn., USA, doi:10.3334/CDIAC/00001_V2012, 2012.

Bovensmann, H., Buchwitz, M., Burrows, J. P., Reuter, M., Krings, T., Gerilowski, K., Schneising, O., Heymann, J., Tretner, A., and Erzinger, J.: A remote sensing technique for global monitoring of power plant $\mathrm{CO}_{2}$ emissions from space and related applications, Atmos. Meas. Tech., 3, 781-811, doi:10.5194/amt-3-781-2010, 2010.

Buchwitz, M., de Beek, R., Noël, S., Burrows, J. P., Bovensmann, H., Bremer, H., Bergamaschi, P., Körner, S., and Heimann, M.:
Carbon monoxide, methane and carbon dioxide columns retrieved from SCIAMACHY by WFM-DOAS: year 2003 initial data set, Atmos. Chem. Phys., 5, 3313-3329, doi:10.5194/acp-53313-2005, 2005.

Corbin, K. D., Denning, A. S., and Gurney, K. R.: The space and time impacts on US regional atmospheric $\mathrm{CO}_{2}$ concentrations from a high resolution fossil fuel $\mathrm{CO}_{2}$ emissions inventory, Tellus B, 62, 506-511, doi:10.1111/j.1600-0889.2010.00480.x, 2010.

Duren, R. M. and Miller, C. E.: Measuring the carbon emissions of megacities, Nature Clim. Change, 2, 560-562, 2012.

Friedlingstein, P., Houghton, R. A., Marland, G., Hackler, J., Boden, T. A., Conway, T. J., Canadell, J. G., Raupach, M. R., Ciais, P., and Le Quere, C.: Update on $\mathrm{CO}_{2}$ emissions, Nat. Geosci., 3, 811-812, 2010.

Gregg, J. S. and Andres, R. J.: A method for estimating the temporal and spatial patterns of carbon dioxide emissions from national fossil-fuel consumption, Tellus B, 60, 1-10, 2008.

Guan, D., Liu, Z., Geng, Y., Lindner, S., and Hubacek, K.: The gigatonne gap in China's carbon dioxide inventories, Nature Clim. Change, 2, 672-675, doi:10.1038/nclimate1560, 2012.

Gurney, K. R., Law, R. M., Denning, A. S., Rayner, P. J., Baker, D., Bousquet, P., Bruhwiler, L., Chen, Y.-H., Ciais, P., Fan, S., Fung, I. Y., Gloor, M., Heimann, M., Higuchi, K., John, J., Maki, T., Maksyutov, S., Masarie, K., Peylin, P., Prather, M., Pak, B. C., Randerson, J., Sarmiento, J., Taguchi, S., Takahashi, T., and Yuen, C.-W.: Towards robust regional estimates of $\mathrm{CO}_{2}$ sources and sinks using atmospheric transport models, Nature, 415, 626630, doi:10.1038/415626a, 2002.

Kalnay, E., Kanamitsu, M., Kistler, R., Collins, W., Deaven, D., Gandin, L., Iredell, M., Saha, S., White, G., Woollen, J., Zhu, Y., Chelliah, M., Ebisuzaki, W., Higgins, W., Janowiak, J., Mo, K. C., Ropelewski, C., Wang, J., Leetmaa, A., Reynolds, R., Jenne, R., and Joseph, D.: The NCEP/NCAR 40-year reanalysis project, B. Am. Meteorol. Soc., 77, 437-471, 1996.

Keppel-Aleks, G., Wennberg, P. O., and Schneider, T.: Sources of variations in total column carbon dioxide, Atmos. Chem. Phys., 11, 3581-3593, doi:10.5194/acp-11-3581-2011, 2011.

Keppel-Aleks, G., Wennberg, P. O., Washenfelder, R. A., Wunch, D., Schneider, T., Toon, G. C., Andres, R. J., Blavier, J.-F., Connor, B., Davis, K. J., Desai, A. R., Messerschmidt, J., Notholt, J., Roehl, C. M., Sherlock, V., Stephens, B. B., Vay, S. A., and Wofsy, S. C.: The imprint of surface fluxes and transport on variations in total column carbon dioxide, Biogeosciences, 9, 875891, doi:10.5194/bg-9-875-2012, 2012.

Kort, E. A., Frankenberg, C., Miller, C. E., and Oda, T.: Space-based observations of megacity carbon dioxide, Geophys. Res. Lett., 39, L17806, doi:10.1029/2012GL052738, 2012.

Le Quéré, C., Raupach, M. R., Canadell, J. G., Marland, G., Bopp, L., Ciais, P., Conway, T. J., Doney, S. C., Feely, R. A., Foster, P., Friedlingstein, P., Gurney, K., Houghton, R. A., House, J. I., Huntingford, C., Levy, P. E., Lomas, M. R., Majkut, J., Metzl, N., Ometto, J. P., Peters, G. P., Prentice, I. C., Randerson, J. T., Running, S. W., Sarmiento, J. L., Schuster, U., Sitch, S., Takahashi, T., Viovy, N., van der Werf, G. R., and Woodward, F. I.: Trends in the sources and sinks of carbon dioxide, Nature Geosci., 2, 831-836, 2009.

Marland, G. and Rotty, R. M.: Carbon-dioxide Emissions From Fossil-fuels - A Procedure For Estimation and Results For 1950- 
1982, Tellus B, 36, 232-261, 1984.

Meehl, G. A., Stocker, T. F., Collins, W. D., Friedlingstein, P., Gaye, A. T., Gregory, J. M., Kitoh, A., Knutti, R., Murphy, J. M., Noda, A., Raper, S. C. B., Watterson, I. G., Weaver, A. J., and Zhao, C.: Global Climate Projections. In Climate Change 2007: The Physical Science Basis. Contribution of Working Group I to the Fourth Assessment Report of the Intergovernmental Panel on Climate Change, Cambridge University Press, 2007.

Miller, C. E., Crisp, D., DeCola, P. L., Olsen, S. C., Randerson, J. T., Michalak, A. M., Alkhaled, A., Rayner, P., Jacob, D. J., Suntharalingam, P., Jones, D. B. A., Denning, A. S., Nicholls, M. E., Doney, S. C., Pawson, S., Boesch, H., Connor, B. J., Fung, I. Y., O'Brien, D., Salawitch, R. J., Sander, S. P., Sen, B., Tans, P., Toon, G. C., Wennberg, P. O., Wofsy, S. C., Yung, Y. L., and Law, R. M.: Precision requirements for space-based $\mathrm{X}_{\mathrm{CO}_{2}}$ data, J. Geophys. Res., 112, D10314, doi:10.1029/2006JD007659, 2007.

Newman, S., Jeong, S., Fischer, M. L., Xu, X., Haman, C. L., Lefer, B., Alvarez, S., Rappenglueck, B., Kort, E. A., Andrews, A. E., Peischl, J., Gurney, K. R., Miller, C. E., and Yung, Y. L.: Diurnal tracking of anthropogenic $\mathrm{CO}_{2}$ emissions in the Los Angeles basin megacity during spring, 2010, Atmos. Chem. Phys. Discuss., 12, 5771-5801, doi:10.5194/acpd-12-5771-2012, 2012.

NRC: Verifying Greenhouse Gas Emissions: Methods to Support International Climate Agreements, National Academies Press, 2010.

O'Dell, C. W., Connor, B., Bösch, H., O'Brien, D., Frankenberg, C., Castano, R., Christi, M., Eldering, D., Fisher, B., Gunson, M., McDuffie, J., Miller, C. E., Natraj, V., Oyafuso, F., Polonsky, I., Smyth, M., Taylor, T., Toon, G. C., Wennberg, P. O., and Wunch, D.: The $\mathrm{ACOS} \mathrm{CO}_{2}$ retrieval algorithm - Part 1: Description and validation against synthetic observations, Atmos. Meas. Tech., 5, 99-121, doi:10.5194/amt-5-99-2012, 2012.

Olsen, S. C. and Randerson, J. T.: Differences between surface and column atmospheric $\mathrm{CO}_{2}$ and implications for carbon cycle research, J. Geophys. Res., 109, D02301, doi:10.1029/2003JD003968, 2004.

Peters, W., Jacobson, A. R., Sweeney, C., Andrews, A. E., Conway, T. J., Masarie, K., Miller, J. B., Bruhwiler, L. M. P., Pétron, G., Hirsch, A. I., Worthy, D. E. J., van der Werf, G. R., Randerson, J. T., Wennberg, P. O., Krol, M. C., and Tans, P. P.: An atmospheric perspective on North American carbon dioxide exchange: CarbonTracker, P. Natl. Acad. Sci., 104, 18925-18930, doi:10.1073/pnas.0708986104, 2007.

Randerson, J. T., Thompson, M. V., Conway, T. J., Fung, I. Y., and Field, C. B.: The contribution of terrestrial sources and sinks to trends in the seasonal cycle of atmospheric carbon dioxide, Global Biogeochem. Cy., 11, 535-560, 1997.

Schneising, O., Buchwitz, M., Burrows, J. P., Bovensmann, H., Reuter, M., Notholt, J., Macatangay, R., and Warneke, T.: Three years of greenhouse gas column-averaged dry air mole fractions retrieved from satellite - Part 1: Carbon dioxide, Atmos. Chem. Phys., 8, 3827-3853, doi:10.5194/acp-8-3827-2008, 2008.

Schneising, O., Buchwitz, M., Reuter, M., Heymann, J., Bovensmann, H., and Burrows, J. P.: Long-term analysis of carbon dioxide and methane column-averaged mole fractions retrieved from SCIAMACHY, Atmos. Chem. Phys., 11, $2863-$ 2880, doi:10.5194/acp-11-2863-2011, 2011.
Takahashi, T., Sutherland, S. C., Sweeney, C., Poisson, A., Metzl, N., Tilbrook, B., Bates, N., Wanninkhof, R., Feely, R. A., Sabine, C., Olafsson, J., and Nojiri, Y.: Global sea-air $\mathrm{CO}_{2}$ flux based on climatological surface ocean $\mathrm{pCO}_{2}$, and seasonal biological and temperature effects, Deep-Sea Res. Part II, 49, 1601-1622, 2002.

Turnbull, J. C., Karion, A., Fischer, M. L., Faloona, I., Guilderson, T., Lehman, S. J., Miller, B. R., Miller, J. B., Montzka, S., Sherwood, T., Saripalli, S., Sweeney, C., and Tans, P. P.: Assessment of fossil fuel carbon dioxide and other anthropogenic trace gas emissions from airborne measurements over Sacramento, California in spring 2009, Atmos. Chem. Phys., 11, 705-721, doi:10.5194/acp-11-705-2011, 2011.

Turnbull, J. C., Tans, P. P., Lehman, S. J., Baker, D., Conway, T. J., Chung, Y. S., Gregg, J., Miller, J. B., Southon, J. R., and Zhou, L.-X.: Atmospheric observations of carbon monoxide and fossil fuel $\mathrm{CO}_{2}$ emissions from East Asia, J. Geophys. Res., 116, D24306, doi:10.1029/2011JD016691, 2011b.

Velazco, V. A., Buchwitz, M., Bovensmann, H., Reuter, M., Schneising, O., Heymann, J., Krings, T., Gerilowski, K., and Burrows, J. P.: Towards space based verification of $\mathrm{CO}_{2}$ emissions from strong localized sources: fossil fuel power plant emissions as seen by a CarbonSat constellation, Atmos. Meas. Tech., 4, 2809-2822, doi:10.5194/amt-4-2809-2011, 2011.

Wunch, D., Wennberg, P. O., Toon, G. C., Keppel-Aleks, G., and Yavin, Y. G.: Emissions of greenhouse gases from a North American megacity, Geophys. Res. Lett., 36, L15810, doi:10.1029/2009GL039825, 2009.

Wunch, D., Toon, G., J.-F. L, Blavier, Washenfelder, R., Notholt, J., Connor, B., Griffith, D., Sherlock, V., and Wennberg, P.: The Total Carbon Column Observing Network, Phil. Trans. R. Soc. A, 369, 2087-2112, 2011.

Wunch, D., Wennberg, P. O., Toon, G. C., Connor, B. J., Fisher, B., Osterman, G. B., Frankenberg, C., Mandrake, L., O’Dell, C., Ahonen, P., Biraud, S. C., Castano, R., Cressie, N., Crisp, D., Deutscher, N. M., Eldering, A., Fisher, M. L., Griffith, D. W. T., Gunson, M., Heikkinen, P., Keppel-Aleks, G., Kyrö, E., Lindenmaier, R., Macatangay, R., Mendonca, J., Messerschmidt, J., Miller, C. E., Morino, I., Notholt, J., Oyafuso, F. A., Rettinger, M., Robinson, J., Roehl, C. M., Salawitch, R. J., Sherlock, V., Strong, K., Sussmann, R., Tanaka, T., Thompson, D. R., Uchino, O., Warneke, T., and Wofsy, S. C.: A method for evaluating bias in global measurements of $\mathrm{CO}_{2}$ total columns from space, Atmos. Chem. Phys., 11, 12317-12337, doi:10.5194/acp11-12317-2011, 2011.

Yokota, T., Oguma, H., Morino, I., and Inoue, G.: A nadir looking SWIR FTS to monitor $\mathrm{CO}_{2}$ column density for Japanese GOSAT project, Proc. Twenty-fourth Int. Sympo. on Space Technol. and Sci. (Selected Papers), 887-889, 2004.

Zhao, Y., Nielsen, C. P., and McElroy, M. B.: China's $\mathrm{CO}_{2}$ emissions estimated from the bottom up: Recent trends, spatial distributions, and quantification of uncertainties, Atmos. Environ., 59, 214-223, doi:10.1016/j.atmosenv.2012.05.027, 2012. 